\title{
Effects of Adenosine on Apoptosis of Ovarian Cancer A2780 Cells via ROS and Caspase Pathways [Corrigendum]
}

Xia B, Wang J. Effects of adenosine on apoptosis of ovarian cancer A2780 cells via ROS and caspase pathways. Onco Targets Ther. 2019;12:9473-9480.

The authors of this paper have advised that Figure 2 is incorrect. The two groups of SKOV3 cells in Figure 2A,
$10 \mathrm{mmol} / \mathrm{L}$ and $20 \mathrm{mmol} / \mathrm{L}$ were duplicated and the two sets of images in Figure 2B, SKOV3 and A2780 cells were duplicated. The authors apologize for this error. The correct figure is below:
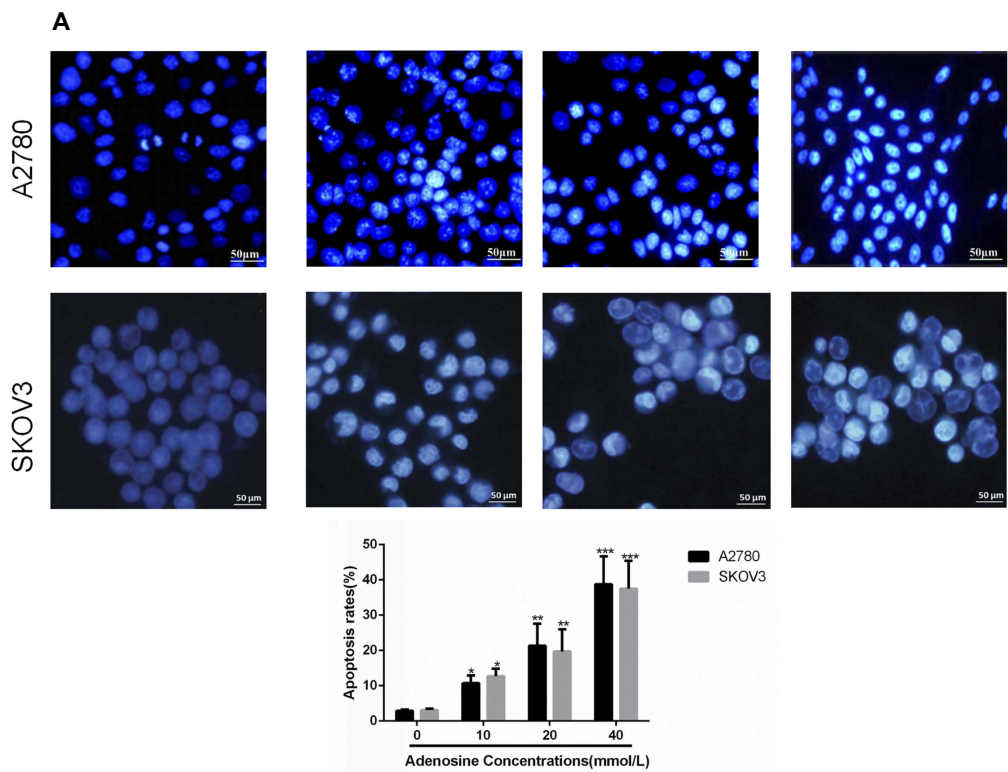

B
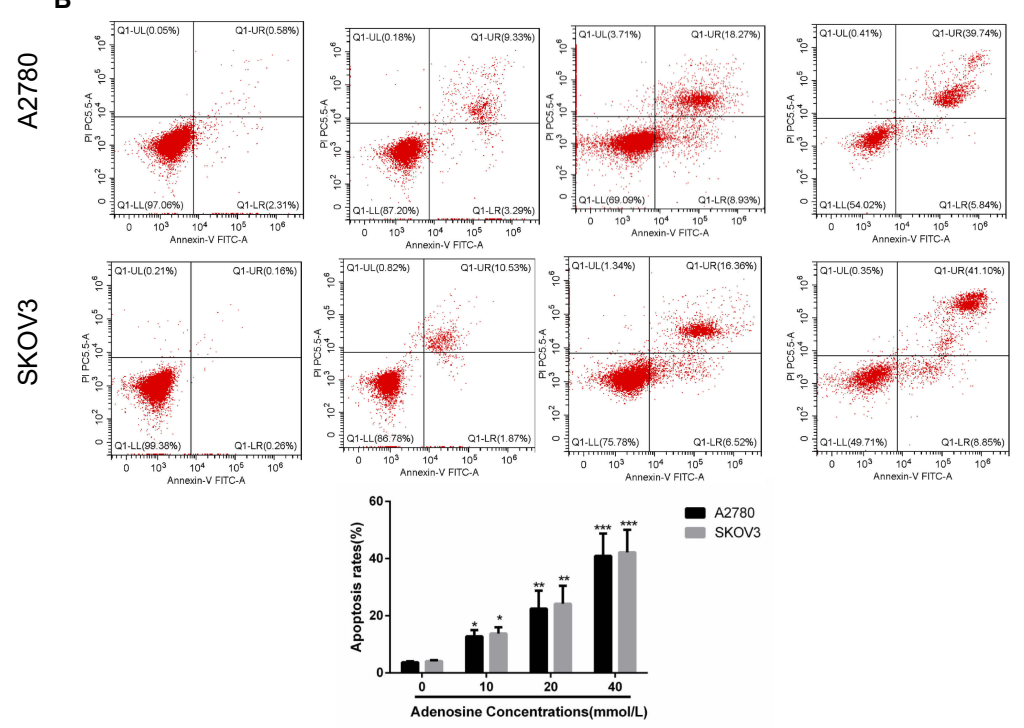

Figure 2 Adenosine-induced apoptosis in ovarian cancer cells.

Notes: A2780 and SKOV3 cells were treated with Adenosine $(0 \mathrm{mM}, 10 \mathrm{mM}, 20 \mathrm{mM}, 40 \mathrm{nM})$ for $24 \mathrm{~h}$. (A) Apoptosis was analyzed using Hoechst 33342 . (B) Apoptosis was analyzed using Annexin-V/PI. $* \mathrm{P}<0.05, * * \mathrm{P}<0.0 \mathrm{I}$, and $* * * \mathrm{P}<0.001$ compared with control. 


\section{Publish your work in this journal}

OncoTargets and Therapy is an international, peer-reviewed, open access journal focusing on the pathological basis of all cancers, potential targets for therapy and treatment protocols employed to improve the management of cancer patients. The journal also focuses on the impact of management programs and new therapeutic agents and protocols on patient perspectives such as quality of life, adherence and satisfaction. The manuscript management system is completely online and includes a very quick and fair peer-review system, which is all easy to use. Visit http://www.dovepress.com/ testimonials.php to read real quotes from published authors. 